\title{
Båtformet, elliptisk eller fusiform hudeksisjon?
}

\author{
Leger jobber med både kniv og ord. Når legen fjerner en hudlesjon med skalpell, skal prosedyren beskrives \\ i journalen på en mest mulig presis, dekkende og korrekt måte.
}

Som lærere på medisinstudiet og veiledere av spesialistkandidater hender det at vi bruker uttrykkene båtsnitt, båteksisjon og båtformet eksisjon ved kirurgisk fjerning av hudlesjoner. Vi har også brukt disse uttrykkene $i$ artikler i Tidsskriftet (1-3) uten at redaksjonen, eksterne fagvurderere eller lesere har reagert. Et sted har vi lært dem, men vi vet ikke helt hvor. Vi har vel ment at de bidrar til at prosedyren blir lettere å forstå.

Ved eksisjon av en hudlesjon foretas først et snitt - en incisjon - $\mathrm{i}$ hudoverflaten. Todimensjonalt kan dette beskrives som et båtformet snitt. Men ved å bruke uttrykket båtformet eksisjon skapes lett assosiasjoner om at vevsbiten som fjernes skal se ut som en robåt med spiss kjøl. Skalpellen blir da holdt $i$ en feil vinkel. Vevsbiten skal snarere likne en flàte med flat bunn og loddrette sideflater (fig 1). Dette er viktig for å få frem at skalpellen ikke skal holdes skrått fra lesjonen som fjernes - snarere skal skalpellen holdes noe skrått mot lesjonen, slik at man lager en svak underminering av de gjenstående kantene.

I medisinsk litteratur brukes vanligvis uttrykket elliptisk eksisjon om denne type eksisjoner (4). Heller ikke dette uttrykket er helt dekkende, for en ellipse er som en «flattrykt sirkel», dvs. at endene er avrundet og ikke spisse (fig 2a). Mange foretrekker derfor heller uttrykket fusiform, der fusi-

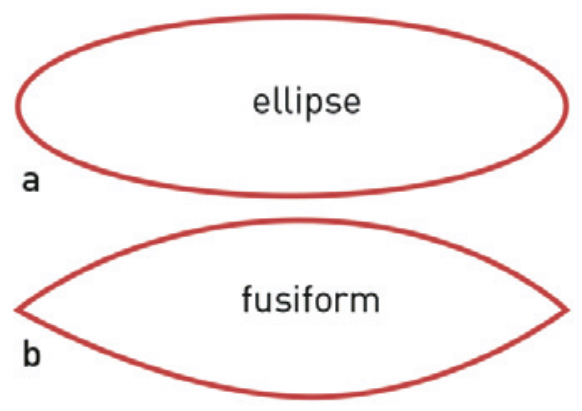

Figur 2 a) Ellipse og b) fusiform figur
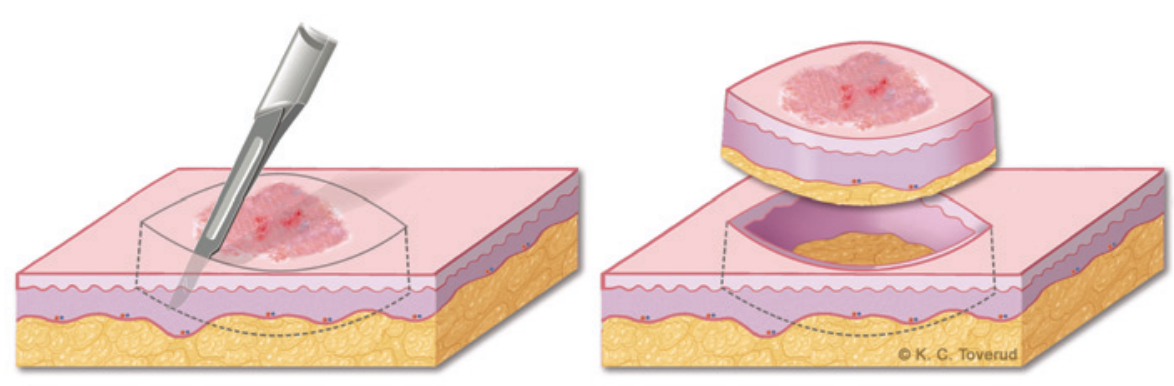

Figur 1 Skisse av korrekt utført eksisjon av hudlesjon

form betyr en lang struktur som er bredest på midten og som smalner av mot hver ende (fig 2b) (5). Uttrykket fusiform eksisjon er imidlertid lite brukt, i Tidsskriftet er det ikke registrert brukt etter $2000 \mathrm{i}$ det hele tatt.

Vi mener altså at uttrykkene båteksisjon og båtformet eksisjon er egnet til å skape misforståelser og kan føre til feil operasjonsteknikk hos uerfarne operatører. Fusiform eksisjon er nok den mest dekkende betegnelsen, men har liten tradisjon i norske fagmiljøer og vil antakelig ha vansker med å få innpass. Mange vil derfor foretrekke uttrykket elliptisk eksisjon, selv om heller ikke dette er helt dekkende. I opplæring av studenter og spesialistkandidater må man uansett valg av betegnelse forklare prosedyren i mer detalj for å sikre at den utføres på korrekt måte.

\section{Petter Gjersvik \\ petter.gjersvik@medisin.uio.no Ingrid Roscher Kim Alexander Tønseth}

Petter Gjersvik (f. 1952) er spesialist i hudog veneriske sykdommer, førsteamanuensis og undervisningsleder i hud-og veneriske sykdommer ved Institutt for klinisk medisin, Universitetet i Oslo.
Ingrid Roscher (f. 1957) er spesialist i hud- og veneriske sykdommer og overlege ved Seksjon for hudsykdommer, Oslo universitetssykehus, med særlig ansvar for kirurgisk behandling av hudkreft.

Kim Alexander Tønseth (f. 1974) er spesialist i plastikkirurgi og er avdelingssjef ved Avdeling for plastikk- og rekonstruktiv kirurgi, Oslo universitetssykehus.

\section{Litteratur}

1. Tønseth KA, Tindholdt TT, Solberg US et al. Keloid og hypertrofisk arrdanning. Tidsskr Nor Lægeforen 2003; 123: 3033-5.

2. Roscher I, Brevig T, Mørk G et al. Mohs' kirurgi ved basalcellekarsinom i ansiktet. Tidsskr Nor Legeforen 2011; 131: 2475-9.

3. Lützow-Holm C, Gjersvik P, Helsing P. Melanom, føflekk eller talgvorte? Tidsskr Nor Legeforen 2013; 133: 1167-8.

4. Goldberg LH, Alam M. Elliptical excisions: variations and the eccentric parallelogram. Arch Dermatol 2004; 140: 176-80.

5. Zuber TJ. Fusiform excision. Am Fam Physician 2003; 67: 1539-44, 1547-8, 1550.

Mottatt 7.7. 2014 og godkjent 5.8. 2014. Redaktør: Marit Skaar Fjellhaug. 